\title{
JINGLE BELLS AND STRUGGLING GIPS: COMPARING THE BALTIC AND THE SOUTHERN EURO ZONE'S CRISIS EXPERIENCE USING THE VARIETIES OF CAPITALISM FRAMEWORK*
}

\author{
Vytautas KUOKŠTIS
}

This article compares the experience of the Baltic countries and the eurozone's southern members, the GIPS (Greece, Italy, Portugal, Spain), in terms of the run-up to the Great Recession and the eurozone crisis, responses during the downturn, and the subsequent recovery (or lack thereof). It discusses numerous apparent similarities in terms of the build-up of macroeconomic vulnerabilities and the content of anti-crisis strategies pursued as well as the substantially different results of these policies. This article applies the VoC (Varieties of Capitalism) approach. To this end, it presents theoretical expectations regarding different varieties' vulnerability to macroeconomic imbalances, preferences regarding anti-crisis policy as well as the likely outcome of the internal devaluation strategy. The article finds the $\mathrm{VoC}$ approach largely useful, although it is more helpful in accounting for the nature of reaction to the crisis and the outcomes of anti-crisis policy, while less so in explaining the initial accumulation of vulnerabilities.

Keywords: Baltic states, GIPS, varieties of capitalism, crisis, internal adjustment, internal devaluation

JEL classification indices: P52

* This work was supported by a Postdoctoral fellowship funded by European Union Structural Fund "Postdoctoral Fellowship Implementation in Lithuania" within the framework of the "Measure for Enhancing Mobility of Scholars and Other Researchers" and the "Promotion of Student Research" (VP1-3.1-ŠMM-01) of the "Program of Human Resources Development Action Plan". Earlier versions of this article were presented at a seminar at the School of Sociology, Politics and International Studies of Bristol University on 13 December, 2013 and the $7^{\text {th }}$ Pan-European Conference on the European Union in the Hague on 5-7 June, 2014. The author is grateful to Magnus Feldmann, Zenonas Norkus, Stefanie Walter, Fabio Bulfone, Martijn Vlaskamp, and Sebastian Dörr for providing valuable comments.

Vytautas Kuokštis, Postdoctoral Fellow at Vilnius University, Faculty of Philosophy, Department of Sociology, Lithuania, and Lecturer at Vilnius University, Institute of International Relations and Political Science. E-mail: kuokstis@gmail.com 


\section{INTRODUCTION}

The three Baltic countries (Estonia, Latvia, and Lithuania) and the southern eurozone members (Greece, Italy, Portugal, and Spain) were among the hardest hit ones during the Great Recession and the eurozone crisis not only in Europe, but in the whole world. Back in 2009, international financial news outlets and economic experts were discussing the precarious situation in the Baltics, in particular their huge pre-crisis imbalances and the chosen policy of internal devaluation. Many were predicting that the Baltic strategy of internal devaluation would fail. However, contrary to these expectations, the Baltics managed to preserve the fixed exchange rate and restore fiscal sustainability. As a result, over the last couple of years, they are often pointed to as successful and even "model" cases of internal devaluation. While in 2008-09 one could refer to the Baltics as the "hELL" countries, these days one might perhaps be tempted to use the much happier-sounding "bELLs" label.

While the crisis receded in the Baltics, southern eurozone members found themselves in deep trouble facing contracting economies along with severe fiscal and banking problems. It was their turn to become the centre of attention of discussions in European and international financial as well as policy-making circles. The "GIPS" countries of Greece, Ireland, Portugal, and Spain faced similar challenges as the Baltics: an overvalued real exchange rate and the associated need to restore competitiveness, current account deficits, worsening fiscal situation and difficulties in accessing credit. Furthermore, they have been pursuing similar anti-crisis policies (internal adjustment, sometimes referred to as internal devaluation) as the Baltics. Nevertheless, despite similar economic challenges and anticrisis policies, the southern eurozone members have been less successful than the Baltics in overcoming the crisis.

The above-mentioned similarities (in terms of economic challenges and responses) and divergences (in terms of outcomes of anti-crisis strategies) make the comparison of these different blocks of countries worthwhile. Furthermore, understanding the causes of the crisis as well as possible solutions to it is of obvious practical relevance for the countries in question as well as for the future functioning and governance of the eurozone. Another motivation for the paper is theoretical - it aims to analyse the above-mentioned developments via the lens of the Varieties of Capitalism ( $\mathrm{VoC}$ ) framework. Despite its popularity, the VoC framework has also faced numerous criticisms, and thus it is interesting to see whether it can shed any light on these developments. It should be noted that earlier literature has already addressed the problems in the European "periphery" from the VoC perspective (see Hall 2012; Hancké 2013; Johnston et al. 2014; Hassel 2014 on the GIPS; Feldmann 2013 on Estonia and Kuokštis 2011 on the 
Baltic countries). Partly building on these arguments, this article makes a contribution in several ways. First of all, to my knowledge, it is the first comprehensive investigation in academic literature of the crisis experience between the European Southern countries and the Baltic ones encompassing the pre-crisis period, responses and the recovery. Second, this article presents an attempt to develop more precise hypotheses regarding different varieties' proclivity towards imbalances and recovery.

The article's first section briefly lays out the VoC framework and describes the types of capitalism existing in the Baltics and the GIPS. The next section develops theoretical expectations that could be generated from the VoC theory. The next three sections constitute the analytical core of the article, dealing respectively with developments prior to the crisis, responses during it, and the outcomes of adjustments. The article finishes with conclusions and discussion of policy issues as well as theoretical implications.

\section{THE VOC FRAMEWORK AND ITS APPLICATION TO THE BALTICS AND THE GIPS}

The VoC approach has become very influential in the field of political economy since the seminal contribution by Hall - Soskice (2001). ${ }^{1}$ The framework puts emphasis on firms as actors and their need to resolve coordination problems within national political economies. Briefly, there are two main ideal types of capitalism: liberal market economies (or LMEs) and coordinated market economies (CMEs). Empirically, the US and the UK are usually considered as the canonical LME models, while Germany is often singled out as the real world case closest to the ideal CME model. LMEs and CMEs have different institutional profiles in many dimensions, including the nature of financial markets, corporate governance, education, welfare, and the labour market. Specifically, LMEs are characterised by the reliance on equity financing, flexible labour markets, limited welfare states, and general skills education, while CMEs rely on "patient capital", high employment protection, extensive welfare regimes, and vocational education systems emphasising specific skills acquisition. Importantly, these configurations are not random, but represent the so-called institutional complementarities. According to Hall - Soskice (2001: 17), "two institutions can be said to be complementary

1 This paper does not present a comprehensive overview of the VoC approach nor its criticisms, as it has already been covered extensively elsewhere, see the seminal contribution by HallSoskice (2001), also Bohle - Greskovits (2009) as well as Hancké et al. (2007) for some of the criticisms and debates surrounding this approach. 
if the presence (or efficiency) of one increases the returns (or efficiency of) the other". Furthermore, there is no single "best" model, as both LMEs and CMEs can be successful and efficient. However, they achieve efficiency differently, as they have their own specific comparative institutional advantages, with LMEs specialising in high-risk innovation (e.g. biotech) and CMEs specialising in incremental innovation (e.g. automobiles and engineering) (Hall - Soskice 2001: 41-44). An interesting and important implication of the $\mathrm{VoC}$ approach is that globalisation, rather than pushing to global convergence on a single "liberal" model, might actually further reinforce the distinct varieties of capitalism as expanding international trade activities enable better use of comparative institutional advantages (Hall - Soskice 2001: 56-60).

It must be noted that the vast majority of research carried out in the VoC strand of literature has focused on developed economies. However, scholars have also attempted to apply this framework to other contexts. Concerning the Baltic countries, although there is no unanimous agreement in the literature, most scholars argue that the Baltic countries represent an LME-type of capitalism (Buchen 2007; Feldmann 2006; Norkus 2008). Controversies arise due to the fact that these countries do not have all the characteristics of LMEs. For instance, Baltic economies do not possess developed equity markets, which are considered to be one of the core institutions of LMEs. In response, authors have argued that the Baltics are "emerging" LMEs and their developmental trajectory since regaining independence in the early 1990s was one of gradual convergence towards the LME model (Norkus 2008; Feldmann 2013).

Several facts make the characterisation of Baltic economies as LMEs compelling. First, the Baltic countries do not have coordinated wage bargaining systems and both employers' and employees' interest organisations are very weak (Norkus 2008). Weak trade unions mean that labour markets in the Baltics are very flexible. This flexibility is further enhanced by the fact that the enforcement of labour regulations is not strong. Besides, the Baltic higher education system is geared towards the development of general, and not specific skills (Feldmann 2006; Norkus 2008; Martinaitis 2012). Furthermore, the Baltics redistribute relatively little and have high income inequalities. State support in terms of unemployment benefits and other social payments is weak, minimum wages are very low. Interestingly, in some respects, they are even more liberal and flexible than paradigmatic LMEs, such as the United States and the United Kingdom (Kuokštis 2011). According to Feldmann (2013: 496), "Estonia could be viewed as a most-likely case for the LME model". Latvia and especially Lithuania also have a very high labour mobility. They are among the leading countries in the EU in terms of emigration. This feature can also be traced to the "flexible" nature of 
Baltic economies where in times of difficulty the unemployed leave the country and apply their "general" skills elsewhere and not put as much strain on public finances (Kuokštis 2011).

As with the Baltics, there is no unanimous consensus in the literature as to which type of capitalism the GIPS countries belong to. Nevertheless, they usually are placed in the "mixed market economy" (or MME) category. According to Molina - Rhodes (2007: 225), "analysing Europe's MMEs requires that attention is paid - as one would expect - to their 'mixed' character and the complexities of their institutional systems". These economies "contain different logics of coordination and forms of actor interaction, making it difficult to talk of one national production model with a single form of comparative advantage" (Molina Rhodes 2007: 225).

A good case in point is the labour market. In contrast to the flexible, fluid labour markets of LMEs, MMEs possess stronger trade unions and also have high employment protection. At the same time, trade unions in MMEs, although strong and able to veto many types of policies, generally have neither the will nor the ability to conduct coordinated wage bargaining. In other words, trade unions are strong enough to demand high wage increases, but not coordinated enough to be able to limit excessive wage growth. Overall, interest associations are highly fragmented and politicised (Molina - Rhodes 2007: 225). As Hancké put it (2013: 91), "cross-industry wage coordination is considerably weaker than in the north of Europe, and as a result inter-sectoral wage drift is endemic". Furthermore, in contrast to CMEs where the leading trade unions come from the tradables sector, in MMEs the sheltered sector (usually the public sector) dominates (Hancké 2013: 97).

The state plays a major role in MMEs. Schmidt (2009) has even suggested calling them "state-influenced market economies" (SMEs). The state is very active in these political economies (more so than in LMEs and CMEs) and tries to compensate for the deficiencies of the MME model because this type of capitalism lacks institutional coherence and is thus less efficient (Molina - Rhodes 2007: 226). In MMEs, the state also serves as "protector" for both individuals (in terms of employment protection) and businesses (barriers to competitive pressures as a result of high product market regulation). According to Hancké (2013: 91), in MMEs, "the state regularly has to step in to compensate for the lack of autonomous bargaining capacity among the key actors". However, this also increases the politicisation of the system and leads to the preservation of economic inefficiencies. 


\section{VOC AND MACROECONOMICS}

In contrast to the insights on microeconomic issues, firm strategies, and production regimes, significantly less attention has been paid in the literature so far to the macroeconomic implications of the VoC framework (Amable - Azizi 2011). Nevertheless, several predictions could be generated. To begin with, on the broadest level, one would expect different forms of capitalisms to "behave" differently. This means that even when facing similar circumstances, different varieties are expected to respond to them distinctively. Furthermore, similar policies implemented in different varieties of capitalism might have diverging outcomes. This also implies that "one-size-fits-all" policies might not be the best solution, and one should be careful about straightforward lesson-drawing based on both successes and failures in other countries.

Second, one of the most interesting predictions of the VoC framework is that "purer" types of capitalism (LMEs as well as CMEs) are expected to perform better than less "pure" ones. Hall - Gingerich (2009) show that both highly coordinated (i.e. non-market coordinated) and highly uncoordinated (i.e. market coordinated) types of capitalisms grow faster than "mixed" (or "hybrid") ones. In a book debating the merits of the $\mathrm{VoC}$ approach, it was concluded that "as evidence from analyses of MMEs and EMEs in this volume and elsewhere reveals [...], the core Hall-Gingerich insight that economies with mixed or poorly calibrated modes of coordination will be outperformed by more coherent systems remains a valuable one" (Hancké et al. 2009: 14).

Turning specifically to macroeconomic issues, one could expect that compared to CMEs, LMEs would be more prone to developing macroeconomic imbalances and financial vulnerabilities as a result of economic "overheating" when the economy operates above capacity (i.e. the output gap is positive). Why could this be the case? The first reason is that LMEs rely heavily on financing from volatile equity markets (as opposed to strategic banking interactions in coordinated market economies, or CMEs) which are known to focus on short-term results and have "impatient" capital. Second, LMEs are less strictly regulated, and thus could allow for more rapid expansion of financial innovation and speculation, which could potentially destabilise the financial system as well as encourage credit bubbles. Third, LMEs have a comparative institutional advantage in private services such as real estate and financial services (Feldmann 2013). Since an expanding financial sector might potentially contribute to asset price bubbles, this gives the third reason why LMEs might be more prone to economic "overheating".

Like LMEs, MMEs are also expected to be more prone to the development of macroeconomic imbalances than CMEs. However, one could expect that this will happen somewhat differently than in LMEs. Specifically, one could expect 
that an important source of this will be their labour market institutions. In MMEs, trade unions are strong enough to exercise bargaining power, but not organised enough to be participants in coordinated, efficient wage bargaining processes. This is especially true in countries where labour is dominated by non-tradable sectors, especially the public sector, which happens to be the case in MMEs (Hancké 2013). Furthermore, in MMEs the state plays an important role. Thus, it might have a tendency to "overspend" and "protect" industries when it has opportunities to do so (i.e. it could be more prone to political business cycles, thus exacerbating competitiveness deterioration during the boom or even starting one). In MMEs, "organized interests use their resources to lobby the state for protection or compensation" (Hassel 2014: 7). Finally, the above-mentioned feature of MMEs - less "purity" on the microeconomic level - also means that there are limited opportunities for productivity growth, which in turn makes them more vulnerable to cost competitiveness deterioration. With regard to the relative inclination of LMEs and MMEs to develop "overheating", expectations are ambiguous. On the one hand, MMEs have "problematic" labour markets, tend to experience lower productivity growth, while the state in MMEs is expected to be more willing to "compensate". On the other hand, LMEs tend to rely on volatile financial markets, have comparative institutional advantage in "bubble-prone" economic sectors, and are less regulated.

Another hypothesis in the VoC literature in terms of macroeconomics is that "nonliberal economies should be expected to have less accommodating (i.e., less countercyclical) macroeconomic policies than liberal varieties" (Amable - Azizi 2011: iii; Amable and Azizi in turn build their arguments on Iversen (2005), Soskice (2007), and Carlin - Soskice (2007)). More specifically, "faced with the same adverse macroeconomic shock, a CME would implement a restrictive budget policy in order to limit the deficit, whereas an LME would choose an expansionary budget deficit to limit the effects of the negative shock on the level of activity or unemployment" (Amable - Azizi 2011: 1). This is because LMEs, due to their limited welfare states, have weaker automatic stabilisers. Second, CMEs tend to prefer a rules-based aggregate demand management regime because of their labour markets. Trade unions' demands for higher wages can translate into higher unemployment, but if they believe that authorities will offset this via expansionary policies, trade unions might be less incentivised to seek wage moderation (Amable - Azizi 2011: 6-7). Thus, for CMEs it might be rational to adopt non-discretionary, rules-based policies. One could also add that due to the above-mentioned reasons (lower propensity for competitiveness losses and macro-imbalances), CMEs are generally expected to face fewer shocks. Even if they do, CMEs can also count on the fact that trade unions will generally be more incentivised to agree with and perhaps even seek wage moderation (because they 
take into account competitiveness), and thus facilitate the adjustment process of cost reduction. Furthermore, trade unions in CMEs dominated by the exposed sector also oppose stimulus policies because this hurts competitiveness (Gabor - Ban 2013: 6). Contrariwise, per their higher propensity for macroeconomic imbalances, LMEs might be more willing to keep the option of stimulating the economy via monetary and fiscal policies in a discretionary manner.

What about MMEs in this regard? 1) MMEs have a rather limited welfare state which translates into fewer automatic stabilisers. ${ }^{2}$ 2) They are more prone to competitiveness deterioration and build-up of imbalances. 3) Contrary to CMEs, MMEs lack coordinated wage bargaining systems which could help bring labour costs down in situations when it is necessary to restore competitiveness. 4) The state plays a very important role in the economy, it attempts to compensate and protect domestic economic actors. 5) MMEs generally lack flexibility, which makes it harder for the economy to adjust. All of these factors imply that MMEs, just as LMEs, should tend to prefer discretionary, accommodative economic policies. Indeed, the historical record of "GIPS" countries shows that before joining the single currency, these countries time and again relied on currency devaluations in response to competitiveness problems. 6) While both LMEs and MMEs are expected to prefer economic stimulus policies during recessions, one could predict that if for some reason they choose (or are forced to) impose austerity, LMEs will tend to respond better than MMEs. This is for several reasons. First, the higher flexibility of labour markets (and overall economy) of LMEs will help them. Second, institutional coherence and the associated institutional complementarities should allow for faster productivity growth (it is of course much easier economically and politically to adjust via higher productivity than lower wages). Third, due to the very important role of the state in MMEs, significant austerity will constitute a more important shock to these economies.

All of the above could also be used to generate a broader insight that generally CMEs will find fixed exchange rate systems (and hence membership in a currency union) more favourable than LMEs and MMEs. Both LMEs and MMEs are more prone to real exchange rate overvaluation and macroeconomic imbalances. Therefore, they are likely to benefit more from macroeconomic discretion in terms of fiscal and monetary policies. During the crisis, they cannot rely on automatic stabilisers as CMEs, they also lack the capacity for wage restraint, which could bring down labour costs to adjust. At the same time, LMEs are expected to perform better than MMEs due to their higher flexibility, more opportunities for productivity growth, and lesser importance of the role of the state.

2 Dolls et al. (2012) show that the Southern eurozone's members have lower automatic stabilisers than Continental and Northern European countries and even the US. 


\section{PRE-CRISIS DEVELOPMENTS}

The start and middle of the first decade of the $21^{\text {st }}$ century was a good one for the Baltics. After experiencing a harsh economic downturn in the wake of the Russian crisis in 1998-1999, the Baltics emerged as one of the fastest growing economies in the world. As a result, in 2003, The Economist (2003) labelled Lithuania the "Baltic tiger" after the country posted a real GDP annual increase of $9 \%$ along with "booming exports, zero inflation, a rock-steady currency, shrinking unemployment and a budget surplus". In Greece and Spain, GDP was also expanding fast. The situation was quite different in Italy and Portugal, though. These economies essentially stagnated during the 2000s (Table 1).

Table 1. Real GDP developments in the Baltics and the GIPS, $2000=100$

\begin{tabular}{l|c|c|c|c|c|c|c}
\hline & 2001 & 2002 & 2003 & 2004 & 2005 & 2006 & 2007 \\
\hline Estonia & 106.3 & 113.3 & 122.0 & 129.8 & 141.3 & 155.5 & 167.2 \\
\hline Latvia & 107.3 & 115.0 & 123.8 & 134.7 & 148.3 & 164.6 & 181.1 \\
\hline Lithuania & 106.7 & 114.0 & 125.7 & 135.0 & 145.5 & 156.9 & 172.2 \\
\hline Greece & 104.2 & 107.8 & 114.2 & 119.2 & 121.9 & 128.6 & 133.2 \\
\hline Italy & 101.9 & 102.3 & 102.3 & 104.0 & 105.0 & 107.3 & 109.1 \\
\hline Portugal & 102.0 & 102.8 & 101.8 & 103.4 & 104.2 & 105.7 & 108.2 \\
\hline Spain & 103.7 & 106.5 & 109.8 & 113.3 & 117.4 & 122.2 & 126.4 \\
\hline
\end{tabular}

Source: Eurostat.

In both the Baltics and the GIPS, the pre-crisis growth relied heavily on domestic demand. Initially, optimism was boosted by structural reforms and EU entrance in 2004 for the Baltics and by eurozone membership for the GIPS countries. Both of these processes, especially entrance into the eurozone, significantly lowered borrowing costs. In the GIPS, credit spreads between the "core" country of Germany and the southern members disappeared. This was related to two factors. First, despite the "no bailout" clause of the Lisbon Treaty, the implicit assumption in financial markets was that no country in the eurozone would be allowed to default. Second, due to the creation of the single currency area, exchange rate risk was (seemingly) eliminated. The latter factor was also important in the Baltic countries, as they had pegged their exchange rates to the euro and were expected to adopt the single European currency in the near future. These developments were also stimulated by loose global monetary policies due to the actions of the American Federal Reserve System as well as "global savings glut" (Marer 2010: 4). 


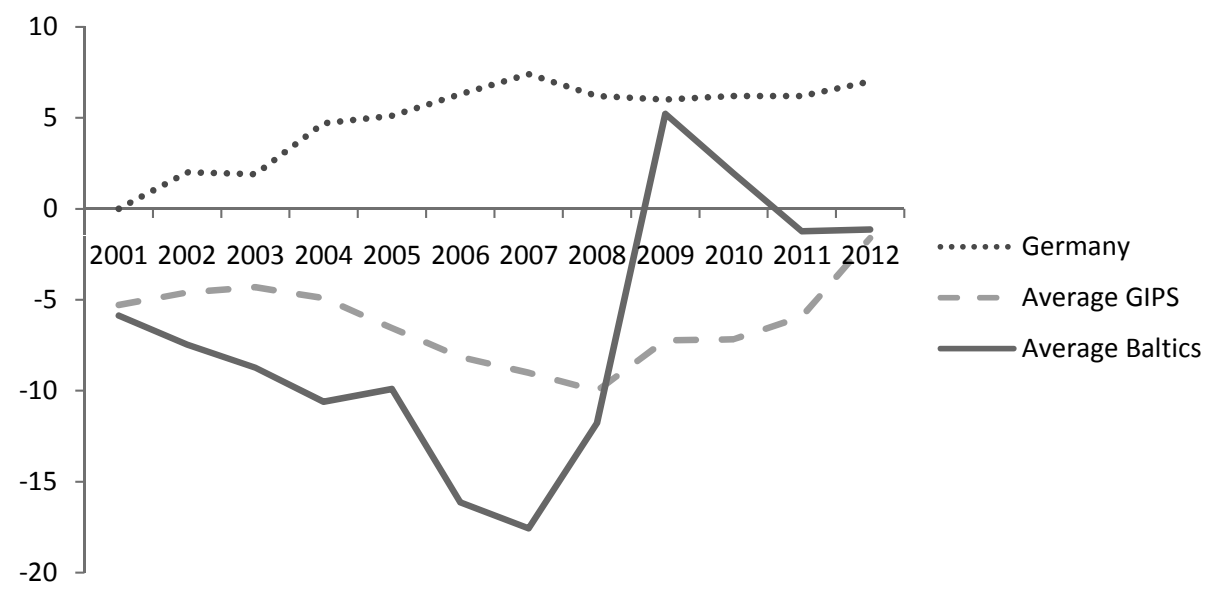

Figure 1. Current account in Germany, the GIPS, and the Baltic states in percentage of GDP (simple unweighted averages taken for the GIPS and the Baltics)

Source: Eurostat, author's calculations.

Cheap credit financed rapid loan growth in both groups of countries. It fuelled consumption and investment, which added to lower unemployment and wage increases as well as inflation. Gradually, as wages were increasing faster than productivity, competitiveness weakened. The high growth of domestic demand and decreasing competitiveness translated into widening current account deficits (Figure 1). Current account deficits meant that countries were accumulating external debts, which in turn left these countries especially vulnerable in the face of a global financial crisis. The situation stands in stark contrast to Germany where the real exchange rate actually depreciated from 2000 to 2008 , and the current account was in substantial surplus.

How can the VoC-perspective inform on the developments that led to the crisis? One of the predictions suggested in the theoretical part was that both LMEs and MMEs are more vulnerable to macroeconomic imbalances and competitiveness problems than CMEs, and in general tend to perform worse under fixed exchange rate systems. This is indeed compatible with the empirical record presented above. Both the Baltic LMEs and the Southern European MMEs gradually lost competitiveness. As Hall (2012: 359) put it, "although largely unacknowledged, a basic asymmetry was built into EMU from its inception". Germany and other Northern CMEs (such as Austria, the Netherlands, and Finland) used the single currency to foster their export-oriented growth model relying on wage restraint and constant productivity gains. In contrast, a domestic demand-led model developed in both 
the GIPS and the Baltics. Furthermore, trade surpluses in CMEs were "recycled" into credit which was channelled back into the GIPS and the Baltics, thus encouraging the divergence even more (see Hall 2012 on the GIPS).

Another theoretical expectation is that different types of capitalism will tend to develop differently. The similar vulnerabilities accumulated by both Baltic LMEs and Southern European MMEs seem to speak against this expectation. Is there any evidence of different processes via which those imbalances were generated? First, there was a substantial difference between the two groups of countries in terms of underlying fundamentals' development - while productivity growth was flat in all Southern countries throughout 2000s, all three Baltic countries experienced substantial and consistent productivity increases (see Appendix 1). This is indeed what we could have expected in terms of "pure" and "hybrid" types of capitalisms.

What about labour markets? As argued in the theoretical section, MMEs can be expected to be especially vulnerable due to their labour market institutions. Indeed, in the GIPS, powerful trade unions dominated by non-tradable sectors - especially the public sector - put up demands for wage growth (Hancké 2013; Johnston et al. 2013). This was because these trade unions did not take into account the deterioration of competitiveness. However, it must also be mentioned that the flexible labour markets in the Baltics substantially overheated as well. In part, as in MMEs, this can be explained by the absence of wage coordination that requires cooperation between trade unions and employers representing the exposed sector (see also Gabor - Ban 2012: 7) according to whom "mixed market economies behave closer to the liberal economies that do not have the institutional constellations to accumulate external surpluses from export activity"). However, two further characteristics also mattered. First, the smallness of Baltic economies meant that capital inflows could "overheat" them more quickly. Second, despite high wage growth, the elimination of barriers to work in other EU states brought by the accession provided huge incentives to emigrate due to substantial wage disparities. In turn, emigration caused labour shortages and added to wage spikes. All in all, however, as labour markets overheated in both groups of countries, the $\mathrm{VoC}$ perspective is not very helpful in differentiating between them. Rather, the imbalances were primarily related to the speculation in real estate (as predicted). At the same time, financial speculation, real estate booms, and private sector overborrowing occurred in the GIPS as well (although the pattern was much more consistent across the Baltic group than the GIPS block). The latter observation makes the $\mathrm{VoC}$ perspective less useful in differentiating the development paths between MMEs and LMEs.

Furthermore, the theoretical discussion raised the possibility that MMEs might be more prone to develop vulnerabilities due to their higher inclination for politi- 
cal business cycles and public overspending. Are these predictions compatible with the empirical record? There is some evidence to suggest that politicians' inclination to add to the boom was stronger in the GIPS than in the Baltic countries. Public deficit figures prior to the crisis show that the Baltic states had lower fiscal deficits prior to the crisis (although Spain is a clear exception, while Greece is the worst outlier) (see Table 2); furthermore, public debt as share of GDP was falling in the Baltics but not the GIPS (with the exception of Spain). Tellingly, Estonia as the most "coherent" LME had budget surpluses (while nominal fiscal deficits in both Latvia and Lithuania as a percentage of GDP were declining).

Table 2. Public balance in percentage of GDP, average of 2001-2007

\begin{tabular}{l|c}
\hline Germany & -2.8 \\
\hline Estonia & 1.4 \\
\hline Latvia & -1.2 \\
\hline Lithuania & -1.4 \\
\hline Greece & -5.8 \\
\hline Italy & -3.3 \\
\hline Portugal & -4.3 \\
\hline Spain & 0.6 \\
\hline
\end{tabular}

Source: Eurostat, author's calculations.

One could respond to this that instead of fiscal political business cycles, Baltic politicians (as well as GIPS governments) engaged in political credit "cycling", as credit to the private sector expanded very rapidly prior to the crisis. While it would be hard to deny that this element played a role, one could make the argument that credit booms in these countries were less a result of an error of commission rather than an error of omission. Take the case of the Baltic countries during the boom years. While it is true that many observers (both foreign and domestic) raised concerns about the very rapid credit growth and real estate bubbles, many predicted or at least expected a "soft landing" scenario. After all, some economists would even argue that bubbles are extremely hard and perhaps impossible to identify and even if they are identified, central banks should not try to burst them. Besides, central banks in the Baltics as well as the GIPS lacked the means to substantially affect credit bubbles. Aside from public persuasion and warnings, the only feasible instrument they possessed in their policy arsenal was bank reserve requirements. However, due to the ability of the subsidiaries of Swedish banks to import capital from mother banks, such a move would have had little effect (in fact, Estonia tightened mortgage credit requirements in early 2006 
(IMF 2006) but this did little to stop the credit boom). Thus, one could say that the relative contribution of deliberate political business cycles was stronger in GIPS compared to the Baltics. However, the importance of this conclusion should be treated with caution, as the primary source of pre-crisis vulnerabilities was mostly related to competitiveness issues and credit growth in the private sector, and less with fiscal profligacy (with the exception of Greece). Prior to the crisis, fiscal deficits in the Baltics were lower than in Germany (see Table 2). As for the GIPS, Spain on average had fiscal surpluses, and both Italy and Portugal did not have fiscal deficits much higher than those in Germany (see also Dăianu 2012). ${ }^{3}$

Overall, the empirical evidence related to VoC's predictions during the pre-crisis period is mixed. On the one hand, there was a substantial difference between the two groups of countries in terms of underlying productivity growth. Second although less importantly -, there is some evidence about the bigger relative contribution of political business cycles to the accumulation of pre-crisis imbalances in the GIPS group (with the exception of Spain) compared to the Baltics. On the other hand, both groups of countries experienced similar problems resulting from excessive wage growth and thus decreasing competitiveness, capital inflows and excessive borrowing.

\section{RESPONSE TO THE CRISIS}

Substantial economic imbalances described in the previous section meant that both the Baltics and the GIPS countries were very vulnerable when the global financial crisis hit. When discussing the crisis experience in these countries, it is also important to remember that they were encountering not "one" crisis, but rather several different, although interrelated, challenges. As discussed by Shambaugh (2012), in the case of the GIPS, there was a banking crisis, a sovereign debt crisis, and an economic growth crisis. A similar story could be told about the Baltic countries, although compared to the GIPS, the Baltics (except for Latvia, see later) had fewer problems in the banking sector, while they faced an even more severe growth crisis, at least in the early years of adjustment (as real GDP in 2009 contracted by double-digit numbers). Furthermore, while those challenges were distinct, the different elements of the crisis reinforced each other, creating a

3 Of course, this does not mean that fiscal policy is not important. Clearly, tighter fiscal policies would have helped to limit economic "overheating”. Furthermore, as shown by Estonia's case, fiscal discipline prior to the crisis helps during it as it provides additional resources for government. Nevertheless, even a very prudent fiscal policy such as the one in Estonia did not help to prevent the build-up of economic imbalances and overheating, or avoid a double-digit economic contraction. 
downward spiral and making adjustment efforts even harder (for instance, lower growth negatively impacted the fiscal situation, while higher public deficits in turn called for more fiscal consolidation, thus suppressing aggregate demand even further) (Shambaugh 2012).

Both the Baltics and the GIPS countries implemented similar anti-crisis policy, namely internal devaluation (sometimes also referred to as internal adjustment). This strategy consisted of two main important components: preservation of the currency peg (in the case of the GIPS, staying in the eurozone) and fiscal consolidation (or adjustment). Furthermore, structural reforms were also pursued. Fiscal consolidation was deemed necessary both to ease balance of payments problems, support downward adjustment of wages and salaries (via lower aggregate demand) as well as in its own right in order to restore fiscal sustainability, which was called into question.

Of the three Baltic countries, only Latvia applied for international financial assistance which was provided by the IMF, the EU, and certain EU member states. Estonia relied on its own fiscal reserves accumulated prior to the crisis, while Lithuania turned to the bond markets to finance the gap between public revenue and expenditure. In contrast to Estonia and Lithuania, Latvia was the only country which had a large bank owned domestically, and its failure aggravated the country's situation. Greece, Portugal, and Spain applied for financial assistance organised by the "Troika" consisting of the EU Commission, the ECB, and the IMF. Under these packages, financial assistance was provided for the southern eurozone members under strict conditions set for both fiscal consolidation and structural reforms.

At first glance, the experience of these countries in terms of response seems to go against VoC predictions, as one would expect different capitalisms to respond differently. According to Hayes et al. (2012: 231), "while responses may vary across the EU in terms of their specific content, pace and degree, common tendencies have emerged across different 'varieties of capitalism'. This development is not easily explained by the $\mathrm{VoC}$ approach, which predicts that responses to 'exogenous shocks' will differ between the varieties of capitalism".

However, a closer scrutiny of policies in the two groups of countries reveals an important difference. First, the Baltics reacted much earlier, faster, and more consistently. Their austerity programs were "heavily front-loaded" (Åslund 2012: 4). This can be partly explained by the fact that the crisis hit the Baltics earlier than it did the GIPS. However, a big part of the explanation is also that austerity is the "primary instinct" of Baltic policy-makers when facing a crisis (Kattel Raudla 2011). Such was the reaction during the Russian crisis in 1997-1998 and earlier, during the period of transition from communism. In contrast, the "primary 
instinct" of policy-makers in Europe's south was to enact macroeconomic stimulus or at least delay austerity as much as possible. For instance, "Spain introduced a package of expansionary measures in 2008 and 2009 totalling 4\% of GDP" (Monastriotis et al. 2013). Having in mind the compensating role of the state in these MMEs, this made sense, although it complicated their fiscal situation down the road. Overall, there was much less sense of an "imposed" policy by external actors (such as the EU or Germany) in the Baltics than in Southern Europe. One could conclude that the Baltics actually "chose" internal adjustment (although this does not necessarily mean that their populations particularly liked it), while the GIPS only started implementing austerity policies when they ran out of all other options. Estonia's case is the most revealing, as it had substantial reserves and thus an option of not pursuing fiscal consolidation (or at least not such a rapid and strong one), but it still went along with the austerity program.

One must also remember the prediction laid out in the theoretical part that LMEs will tend to prefer economic stimulus policies during the crisis. This is at odds with the Baltic response. However, if we adopt the "spirit" of the VoC perspective and look closely at the institutional set-up as well as other background conditions, we can find the logic behind the Baltic response. The theory why LMEs should tend to implement stimulus relies on the assumption that such political economies possess few automatic stabilisers. But this ignores the possibility that the problem of excessive unemployment can be addressed in other ways. In the Baltics, policymakers could expect to rely on traditionally high labour mobility. In turn, this can be attributed to the high flexibility of their labour markets. Second, another difference between established LMEs and Baltic political economies was an even lower importance of the state in economy in terms of public goods provision and support for investment into research and development (Kuokštis 2011). Thus, austerity policies could be considered to be less detrimental to these countries' production profiles. Third, the even higher flexibility of Baltic labour markets compared to canonical LMEs meant that the adjustment process could be expected to be faster. Interestingly, as suggested by Feldmann (2013: 499) on Estonia's internal devaluation, "this adjustment strategy and the fact that wages were relatively flexible downwards could also suggest the Estonian political economy may come closer to the theoretical ideal type of a pure LME than the canonical examples of LME economies, like the UK or the US, given this strong emphasis on market-based adjustment mechanisms". As shown by Walter (2014), the Baltic countries (in contrast to the GIPS block) were relatively less vulnerable to internal compared to external adjustment (currency devaluation). 


\section{OUTCOMES OF THE ANTI-CRISIS POLICY}

Following a very steep decline, the Baltic economies rebounded quickly. In contrast, the GIPS block continues to struggle. While the situation stabilised after ECB's president Draghi's comments about the readiness to "do whatever it takes" to save the eurozone, clearly the southern eurozone members are not out of the woods yet. In terms of unemployment, as shown in Figure 2, it shot up fast in the Baltics from 2007 to 2010, but then started falling. In contrast, the average unemployment rate in the GIPS, although below the Baltic one in 2009 and 2010, in 2012 was already higher and increased further in 2013. It fell only slightly in 2014.

How can we explain this divergence between the GIPS and the Baltics? Can the differences in these countries' institutional arrangements described earlier account for it, as suggested by the $\mathrm{VoC}$ framework? To begin with, one should name several important additional factors which can help to account for the difference in outcomes. First, the Baltics were much smaller and open economies, which meant that it was easier for them to "export themselves out" of the crisis. This also meant that contractionary fiscal policy was relatively less painful due to lower multipliers. Secondly, with the exception of Latvia, they did not face major problems in the banking sector, contrary to what happened in the GIPS. Third, coming into the crisis, their public debts were significantly lower and this helped to escape the vicious circle of low economic growth and high public debt. Finally,

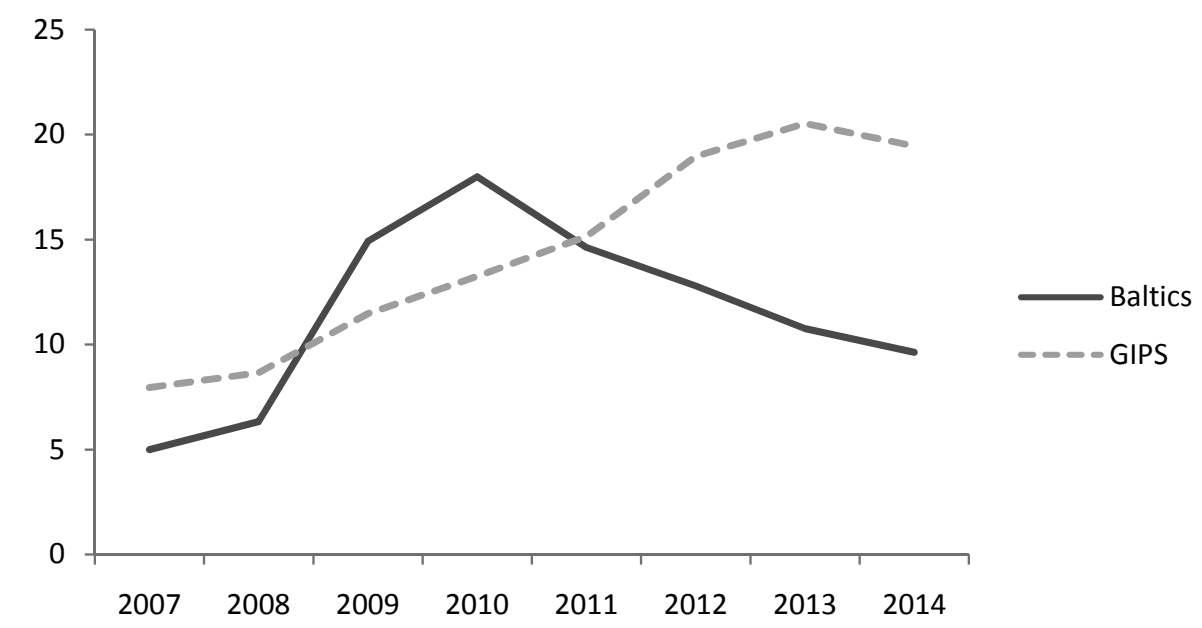

Figure 2. Unemployment rate in the Baltics and the GIPS, in percentage (simple unweighted averages)

Source: Eurostat, author's calculations. 
Kattel - Raudla (2013) mention that the use of EU structural funds substantially helped the Baltic countries during the downturn and partly compensated for the budget revenue loss. ${ }^{4}$

That said, several important aspects of the diverging outcomes can be explained by the VoC perspective. To begin with, while it is true that smallness (and thus openness) helped the Baltic countries, it is also true that due to their exceptional flexibility, the Baltics were able to use this opportunity more successfully. An important part of this was wage flexibility (Purfield - Rosenberg 2010) although it should be mentioned that wages in the private sector decline significantly less than in the public sector (see Appendix 2 for the comparison of wage adjustment in the Baltics and the GIPS). In contrast, it took longer for wages in Portugal and Greece to start falling, while in Italy and Spain - despite substantial growth of unemployment - nominal wages essentially did not adjust during the crisis (see Appendix 2; also O'Rourke - Taylor 2013). It must also be recognised that taking into account a longer time-frame, nominal wages have now adjusted more in Portugal and Greece than in the Baltic countries. Nevertheless, one must have in mind that by 2010-2011 the adjustment process in the Baltic countries was essentially over, and wages started increasing in response to falling unemployment.

However, in the Baltics this flexibility encompassed other important dimensions apart from nominal downward wage adjustment. One of them was emigration. In response to the crisis, outward migration increased substantially in Latvia and especially in Lithuania. This eased the pressures on state budgets and the whole economy, at least in the short-term. In turn, part of the explanation for high emigration can be linked to the "general skills" education and lack of supporting welfare spending in the Baltics, which are characteristic of the Baltic model (Kuokštis 2011).

Another dimension of flexibility was related to business strategies. It is true that downward nominal wage adjustment helped. However, the contribution of productivity growth to declining unit labour costs was even stronger, especially in the tradable sector (as noted by Blanchard et al. (2013) in Latvia's case). Baltic firms were able to adjust fast and reorient themselves towards exports. As Figure 3 reveals, bigger adjustments in the real effective exchange rate (REER) (based on unit wage costs in manufacturing, which serves as a proxy for the tradable sector) were positively associated with higher exports growth during the crisis.

4 Regarding this point, however, one must remember that even with the higher use of EU financing fiscal consolidation in the Baltic countries was very substantial (see, for instance, Krals 2014). Furthermore, GIPS, although to a lesser extent, also benefited from EU structural funds; they also relied on other forms of financing available to eurozone members, namely European Stability Mechanism and also the TARGET2 system). 


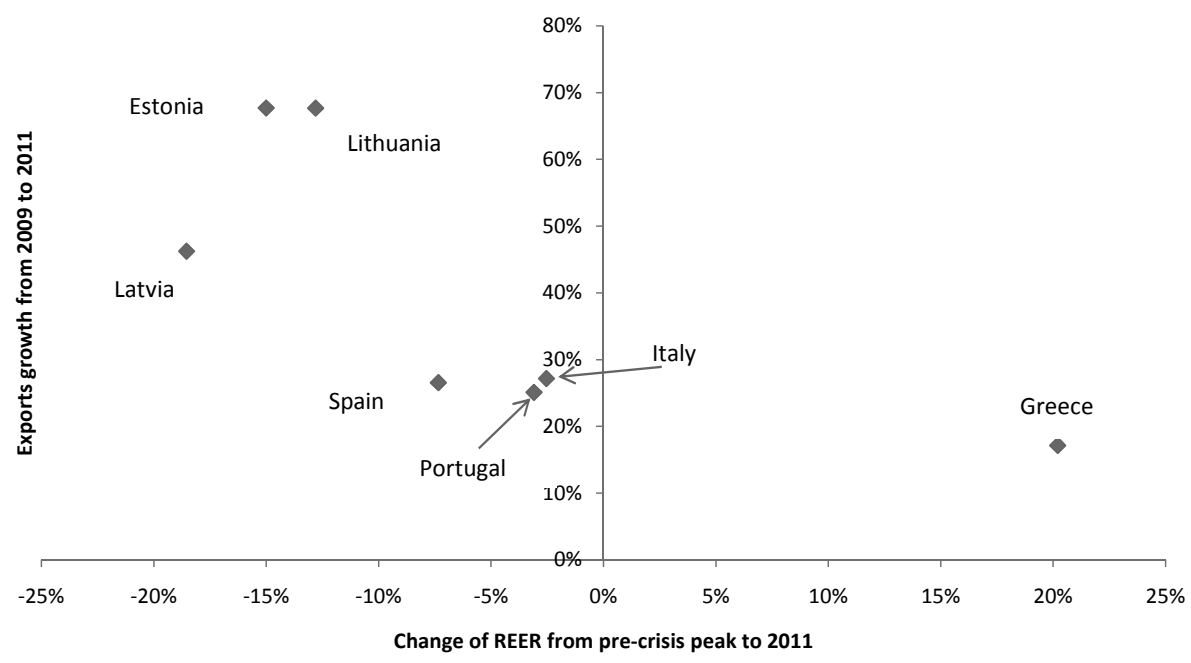

Figure 3. Change in real effective exchange rate (REER) and exports growth, $\%$

Notes: Real effective exchange rate is based on unit wage costs in manufacturing and was calculated from precrisis peak year to 2011. Exports' growth was calculated from 2009 to 2011.

Source: AMECO database for REER; Eurostat for exports; author's calculations.

As Blanchard et al. (2013) note in analysing Latvia's case, this was unexpected and quite a puzzle in the light of macroeconomic theory. This aspect deserves further scrutiny in the future, but a tentative explanation as to why this happened can be provided. Going back to the description of the Baltic model, it was stated that these economies, to use Karl Polanyi's terminology, have relatively few signs of "protective countermovement" from the market forces (see also Bohle - Greskovits 2012) who, inspired by a Polanyian perspective, conceptualise the Baltic regime as "neoliberal" characterised by high efficiency and macroeconomic discipline but also higher inequality and low "protection"). This is true for the population at large in terms of limited unemployment benefits and general compensation, but also for businesses (few subsidies and very limited industrial policy) (Bohle - Greskovits 2012). When economic conditions turn sour, the state does not come in and "protect" ("compensate") for the downturn. Instead, Baltic firms are largely left on their own. One could therefore hypothesise that over time they have become accustomed to wide fluctuations in economic conditions and thus more adaptable to changing circumstances. Furthermore, low state involvement (in the form of unemployment benefits, automatic stabilisers, etc.) helped in terms of putting less pressure on the state budget benefits, which in turn eased 


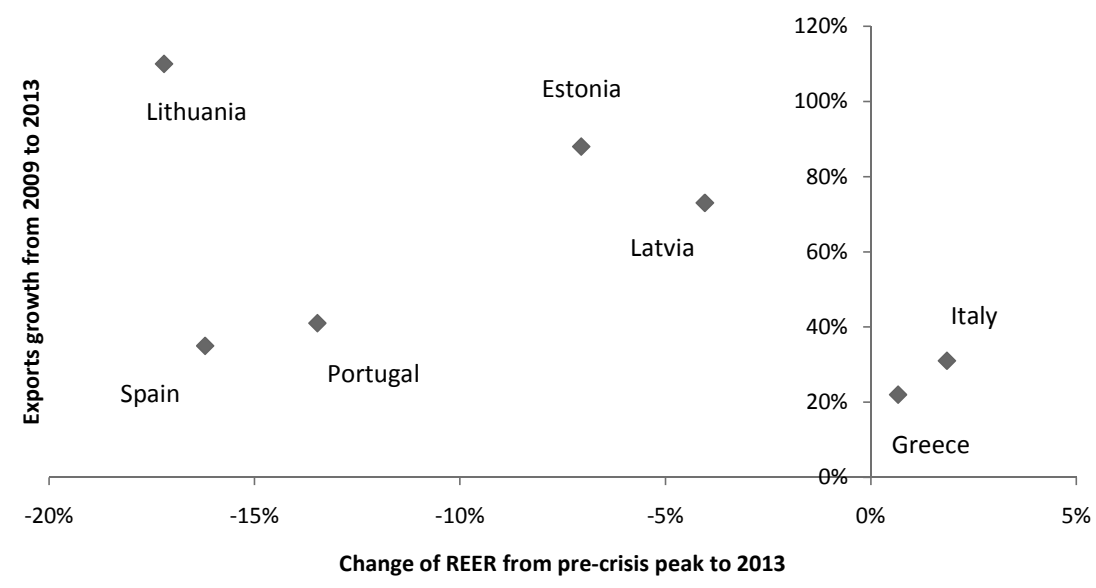

Figure 4. Change in real effective exchange rate (REER) and exports growth, $\%$

Notes: Real effective exchange rate is based on unit wage costs in manufacturing and was calculated from precrisis peak year to 2013. Exports' growth was calculated from 2009 to 2013

Source: AMECO database for REER; Eurostat for exports; author's calculations.

the fiscal situation and helped to pursue fast fiscal consolidation. Finally, Kattel - Raudla (2013) mention that the use of EU structural funds substantially helped the Baltic countries during the downturn and partly compensated for the revenue loss. Last but not least, one should also note that what happened in the Baltics during the adjustment was a continuation of a historically strong productivity growth mentioned previously (see also Appendix 1 as well as Blanchard et al. on Latvia 2013: 351).

Finally, even changes in cost competitiveness (as captured by relative unit labour costs) do not necessarily tell the whole story. First, what matters is not only the price, but also quality of exports. Furthermore, even if potentially attractive opportunities exist in the tradable sector, reallocation might be hindered due to factors such as barriers to entry, excessive product and labour market regulation, etc. GIPS countries compare unfavourably on these dimensions with the Baltic States. ${ }^{5}$ If one looks at the data extending to 2013 (see Figure 4), Spain and Portugal in fact have already adjusted more in terms of cost competitiveness compared

5 For instance, according to the "ease of doing business" score in the World Bank's Doing Business Report (2008), Estonia is in the $17^{\text {th }}$ place, Latvia in the $22^{\text {nd }}$, and Lithuania in the $26^{\text {th }}$. Contrast that to GIPS' rankings: Portugal takes the $37^{\text {th }}$ place, Spain the $38^{\text {th }}$ place, Italy comes in the $53^{\text {rd }}$ place, while Greece only takes the $100^{\text {th }}$ place. 
to Latvia and Estonia (as mentioned above, adjustment was essentially over in the Baltics by 2011, and subsequently wages started increasing), but were still lagging behind in terms of exports' growth (although they performed better than Greece and Italy, which corroborates the general relationship between cost competitiveness and exports). According to Tressel - Wang (2014: 10), in the GIPS "the data suggests that there is little evidence that a real reallocation of resources has so far taken place between tradable and non-tradable sectors". Furthermore, they find that among non-cost factors positively influencing exports performance in the eurozone, lower business cost (cost of starting a business) and lower employment protection stand out as significant predictors. Factors hindering sectoral reallocation and productivity growth, such as high labour and product market regulation and lack of competition, are characteristic of the "mixed" Southern European political economies.

\section{CONCLUSIONS AND IMPLICATIONS}

The experience of the Baltic countries has been the topic of many policy-related discussions, and the situation in the GIPS countries even more so. A VoCinformed perspective presents a valuable corrective to a popular view attributing troubles to largely irresponsible fiscal policies and policy mistakes (Hall 2012; Hancké 2013; Johnston et al. 2013; see also Dăianu 2012 for a similar conclusion, although from a different theoretical perspective). It also encourages one to question the one-size-fits-all thinking, for instance that economic flexibility is the only way for countries to recover. At the same time, one could also criticise the policy views provided by authors who discussed the situation in the eurozone coming from the $\mathrm{VoC}$ perspective.

This is because it is hard to be satisfied with the policy alternatives offered. Hall (2012) rejects the advice for everyone to become "more flexible" and pursue fiscal consolidation, but he does not offer any substantial alternatives. Hancké does provide more specific policy solutions. He suggests that a "proper fiscal union" should be created to counteract "excessive inflation divergence when it emerges" (2013: 100), and, secondly, that "Germany and its northern neighbours would have to rethink their domestic economies away from the massive reliance on exports to the rest of EMU, and adopt more classical Keynesian policies geared toward managing domestic demand". The trouble with these solutions, however, is that they are politically unrealistic. Besides, these authors hardly talk about doing anything with the institutional arrangements within the GIPS. This is strange, because a VoC-informed perspective would actually point at institutional deficiencies/non-complementarities as the primary potential source of trouble 
giving rise to lack of competitiveness in the southern economies. In other words, such a perspective would suggest implementing reforms that would direct the southern economies either towards an LME or a CME type of capitalism. Of course, such reforms are expected to bear fruit only in the longer run, and can be very costly in the short run, both economically and politically.

As for the Baltic economies, while the VoC perspective can inform us as to how the Baltic countries adjusted during the crisis, it also provides certain concerns about the future of these economies. First, it was mentioned in this article that a big reason why the Baltics recovered fast was an unexpected increase in productivity. It is reasonable to suggest that in the future, such opportunities for very fast and big productivity increases will be smaller. Second, if the $\mathrm{VoC}$ framework is correct, one could expect that when (if) the Baltics mature into "advanced" LME-types and fully develop the corresponding institutional prerequisites, the state will need to play a bigger role. In LMEs, the state is actively involved in supporting basic research and developments activities which are not sufficiently financed by private actors due to their public good nature. As the state begins to play a more active role in these activities in the Baltics, it will likely need higher fiscal capacities, which in turn might preclude fast and extensive fiscal consolidation in the future. Overall, the Baltics in the future might find it beneficial to rethink their adjustment processes along the lines of adjustments in the small Western countries which, as famously discussed by Katzenstein (1985), used to adjust "flexibly", but in a very different way (see also Kuokštis 2015).

As for theoretical implications, the analysis in this article has largely found the $\mathrm{VoC}$ framework useful, although this perspective should also be supplemented by the analysis of additional, contextual factors. Furthermore, this perspective turned out to be relatively more successful at explaining the responses to and recovery (or lack thereof) from the crisis. The internal devaluation response was more in line with the nature of the Baltic political economies, and subsequently they responded to the policy better due to higher flexibility and more opportunities for productivity growth. In terms of pre-crisis developments, although the VoC perspective did generate some useful insights (most importantly, related to higher productivity growth in LMEs compared to MMEs), it was not very useful in distinguishing between the paths of imbalances between the two groups of countries.

The discussion in this article also points to two aspects that are worth paying attention to more closely. First, on a broad level, the implications of the VoC framework for macroeconomic issues need to be investigated more thoroughly. Second, on a more specific note, the analysis suggests that the macroeconomic framework might matter in terms of how well different types of capitalism perform. Namely, CMEs are expected to perform ceteris paribus better under fixed 
exchange rate regimes than LMEs and especially MMEs. In fact, the analysis provided here suggests another channel which could explain why "hybrid" capitalisms might be less efficient over the long run, namely that MMEs are both more prone to macroeconomic imbalances and find it hard to adjust to them, especially if they adopt fixed exchange rates.

Finally, an important caveat is in order. To account for the developments in the Baltic countries and the GIPS group, this article relied on the VoC framework which puts primary emphasis on economic-structural factors. It therefore neglected important political-institutional factors such as interest groups, party politics, and ideas. This was done to provide a more parsimonious explanation as well as to see how far the VoC framework can "carry" us. For instance, Kattel Raudla (2013) attribute the Baltic response to specific ideas and institutional inertia in terms of policy-making rather than economic structure (as was done in this article). It is worthwhile to compare different explanatory perspectives in future research (although it would be surprising if the Baltic responses did not reflect at least some underlying economic logic, as also revealed by their subsequent relatively successful recovery).

Another way to extend the analysis is to look into other countries' experience. Ireland seems to be a good candidate in this regard. Furthermore, a preliminary view of Ireland's experience seems to be compatible with the framework outlined in this article. Ireland, like the Baltic countries, is generally considered to be an LME. And, indeed, in many ways Ireland seems to have "behaved" similarly to the Baltic countries during the crisis. Compared to the Southern eurozone economies, it reacted earlier and faster and recovered more successfully (Tressel - Wang 2012), to a large extent relying on exports' growth (see also Regan (2012) who discusses Ireland's crisis experience from a VoC-inspired perspective). Finally, one could also test the theoretical predictions suggested in this article regarding different varieties' behaviour before, during and after the crisis in a large- $\mathrm{N}$ setting.

\section{REFERENCES}

Amable, B. - Azizi, K. (2011): Varieties of Capitalism and Varieties of Macroeconomic Policy: Are Some Economies more pro-Cyclical than Others? Max Planck Institute Working Paper 11/6. Available at http://www.mpifg.de/pu/mpifg_dp/dp11-6.pdf (accessed 17 March 2014).

Åslund, A. (2012): Southern Europe Ignores Lessons from Latvia at Its Peril. Peterson Institute for International Economics, Policy Brief, No. PB12-17. Available at http://boodstore.iie.com/ publications/pb/pb12-17.pdf (accessed 12 January 2014).

Blanchard, O. - Griffiths, M. - Gruss, B. (2013): Boom, Bust, Recovery: Forensics of the Latvia Crisis. Brooking Papers on Economic Activity, Fall: 325-388.

Bohle, D. - Greskovits, B. (2009): Varieties of Capitalism and Capitalism «tout court». European Journal of Sociology, 50(03): 355-386. 
Bohle, D. - Greskovits, B. (2012): Capitalist Diversity on Europe's Periphery. Ithaca: Cornell Univeristy Press.

Buchen, C. (2007): Estonia and Slovenia as Antipodes. In: Lane, D. - Myant, M. (eds): Varieties of Capitalism in Post-Communist Countries. Houndmills: Palgrave, 65-86.

Carlin, W. - Soskice, D. (2009): German Economic Performance: Disentangling the Role of Supply-Side Reforms, Macroeconomic Policy and Coordinated Economy Institutions. Socio-Economic Review, 7(1): 14-61.

Dăianu, D. (2012): Eurozone Crisis and EU Governance: Tackling a Flawed Design and Inadequate Policy Arrangements. Acta Oeconomica, 62(3): 295-319.

Dolls, M. - Fuest, C. - Peichl, A. (2012): Automatic Stabilizers and Economic Crisis: US vs. Europe. Journal of Public Economics, 96(3-4): 279-294.

Feldmann, M. (2006): Emerging Varieties of Capitalism in Transition Countries Industrial Relations and Wage Bargaining in Estonia and Slovenia. Comparative Political Studies, 39(7): 829-854.

Feldmann, M. (2013): Varieties of Capitalism and the Estonian Economy: Institutions, Growth and Crisis in a Liberal Market Economy. Communist and Post-Communist Studies, 46(4): 493-501.

Gabor, D. - Ban, C. (2013): Fiscal Policy in (European) Hard Times: Financialization and Varieties of Capitalism. Unpublished manuscript. Available at http://papers.ssrn.com/sol3/papers. cfm?abstract_id=2201518 (accessed 11 August 2014).

Hall, P. (2012): The Economics and Politics of the Euro Crisis. German Politics, 21: 355-371.

Hall, P. - Gingerich, D.W. (2009): Varieties of Capitalism and Institutional Complementarities in the Political Economy: An Empirical Analysis. British Journal of Political Science, 39(3): 449-482.

Hall, P. - Soskice, D. (eds) (2001): Varieties of Capitalism: The Institutional Foundations of Comparative Advantage. Oxford: Oxford University Press.

Hancké, B. (2013): The Missing link: Labour Unions, Central Banks and Monetary Integration in Europe. Transfer: European Review of Labour and Research, 19(1): 89-101.

Hancké, B. - Rhodes, M. - Thatcher, M. (2007): Beyond Varieties of Capitalism: Conflict, Contradictions, and Complementarities in the European Economy. Oxford: Oxford University Press.

Hassel, A. (2014): Adjustments in the Eurozone: Varieties of Capitalism and the Crisis in Southern Europe. LSE 'Europe in Question' Discussion Paper Series, No. 76/2014. Available at http:// www.lse.ac.uk/europeanInstitute/LEQS/LEQSPaper76.pdf (accessed 11 August 2014).

Hayes, J. - Lewis, P. - Clark, I. (2012): Varieties of Capitalism, Neoliberalism and the Economic Crisis of 2008-? Industrial Relations Journal, 43(3): 222-241.

IMF (2006): IMF Staff Visit to Estonia - Concluding Statement. April 5. Available at http://www. imf.org/external/np/ms/2006/040506.htm (accessed 24 August 2014).

Iversen, T. - Soskice, D. (2010): Responding (or Not) to Economic Shocks: Three Patterns of Reforms and Macroeconomic Adjustment. Paper presented at the Conference "Comparative Responses to the Economic Crisis in Advanced Industrial States", Princeton University, March 27-29.

Johnston, A. - Hancké, B. - Pant, S. (2014): Comparative Institutional Advantage in the European Sovereign Debt Crisis. Comparative Political Studies, 47(13): 1771-1800.

Kattel, R. - Raudla, R. (2011): Why did Estonia Choose Fiscal Retrenchment after the 2008 Crisis? Journal of Public Policy, 31(2): 163-186.

Kattel, R. - Raudla, R. (2013): The Baltic Republics and the Crisis of 2008-2011. Europe-Asia Studies, 65(3): 426-449.

Katzenstein, P. (1985): Small States in World Markets: Industrial Policy in Europe. Ithaca: Cornell University Press. 
Krals, D. (2014): The Political Economy of Crisis Adjustment in Central and Eastern Europe. Economics and Business Working Paper No. 132.

Kuokštis, V. (2011): What Type of Capitalism do the Baltic Countries Belong To? Emecon 1. Available at http://www.emecon.eu/current-issue/second/vytautas-kuokstis/ (accessed 17 of March 2014).

Kuokštis, V. (2015): Baltic States in World Markets. Does Katzenstein's Framework Still Hold? Journal of Baltic Studies, 46(2): 109-126.

Marer, P. (2010): The Global Economic Crisis: Impacts on Eastern Europe. Acta Oeconomica, 60(1): 3-33.

Martinaitis, Ž. (2012): The Political Economy of Skills Formation: Explaining Differences in Central and Eastern Europe. Doctoral dissertation, Vilnius University. Available at http://vddb.library.lt/obj/LT-eLABa-0001:E.02 2010 D_20101102_153847-42081 (accessed 12 of January 2014).

Molina, O. - Rhodes, M. (2007): The Political Economy of Adjustment in Mixed Market Economies: A Study of Spain and Italy. In: Hancké, B. - Rhodes, M. - Thatcher, M. (eds): Beyond Varieties of Capitalism: Conflict, Contradictions, and Complementarities in the European Economy. Oxford: Oxford University Press, 223-252.

Monastriotis, V. - Hardiman, N. - Goretti, A. (2013): Austerity Measures in Crisis Countries - Results and Impact on Mid-Term Development. Intereconomics, 48(1): 4-32.

Norkus, Z. (2008): Lietuva tarp Estijos ir Slovėnijos: dèl pokomunistinio kapitalizmo tipologinès diferenciacijos. Politologija, 49(1): 42-84.

Norkus, Z. (2012): On Baltic Slovenia and Adriatic Lithuania: A Qualitative Comparative Analysis of Patterns in Post-Communist Transformation. Vilnius: Apostrofa/CEU Press.

O'Rourke, K. - Taylor, A. (2013): Cross of Euros. The Journal of Economic Perspectives, 27(3): 167-191.

Polanyi, K. (1957): The Great Transformation: The Political and Economic Origins of Our Time. Boston: Beacon Press.

Purfield, C. - Rosenberg. C. (2010): Adjustment under a Currency Peg: Estonia, Latvia and Lithuania during the Global Financial Crisis 2008-09. IMF Working Paper WP/10/213.

Regan, A. (2012): The Political Economy of Social Pacts in the EMU: Irish Liberal Market Corporatism in Crisis. New Political Economy, 17(4): 465-491.

Schmidt, V. (2009): Putting the Political Back into Political Economy by Bringing the State Back in yet Again. World Politics, 61(3): 516-546.

Shambaugh, J. (2012): The Euro's Three Crises. Brookings Papers on Economic Activity, Spring: $157-231$

Soskice, D. (2007): Macroeconomics and Varieties of Capitalism. In: Hancké, B. - Rhodes, M. Thatcher, M. (eds): Beyond Varieties of Capitalism: Conflict, Contradictions, and Complementarities in the European Economy. Oxford: Oxford University Press, 89-121.

The Economist (2003): Baltic Tiger. July 17. Available at http://www.economist.com/node/1929205 (accessed 12 January 2014).

Tressel, T. - Wang, S. (2014): Rebalancing in the Euro Area and Cyclicality of Current Account Adjustments. IMF Working Paper WP/14/130.

Walter, S. (2014): Distributing the Pain Vulnerability to Adjustment and Crisis Politics in Balanceof-Payments Crises. Paper presented at the Annual Meeting of the American Political Science Association in Washington, DC, August 28-31. 


\section{APPENDIX 1}

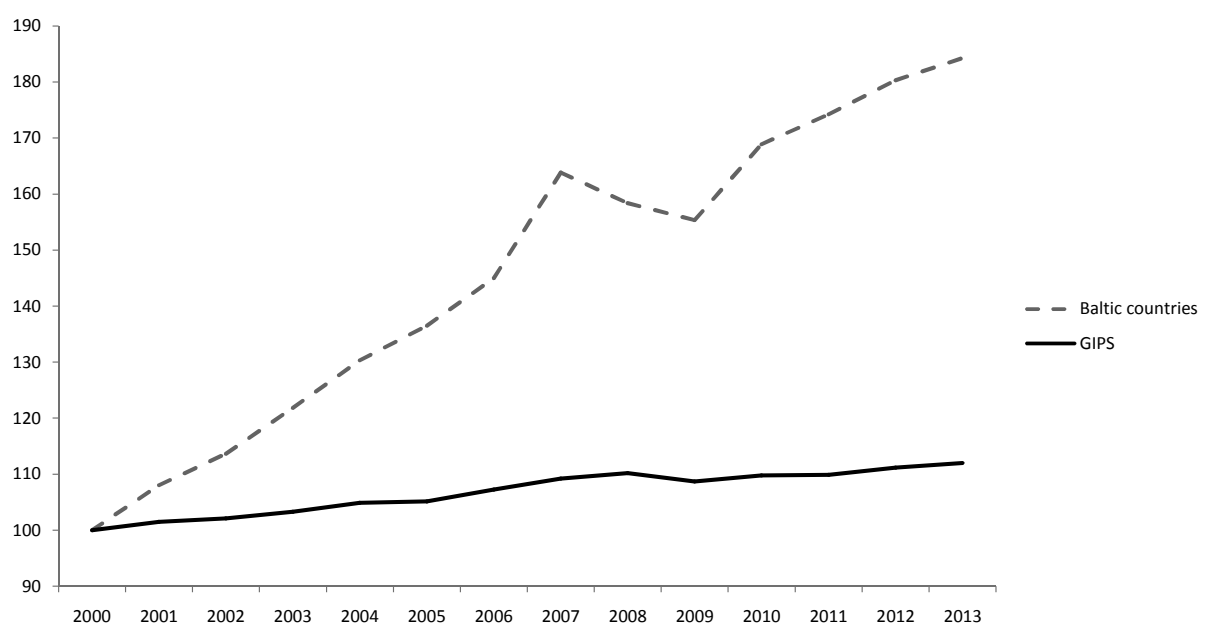

Labour productivity per hour worked in the GIPS and the Baltics

(simple unweighted averages), $2005=100$.

Source: Eurostat, author's calculations. 


\section{APPENDIX 2}
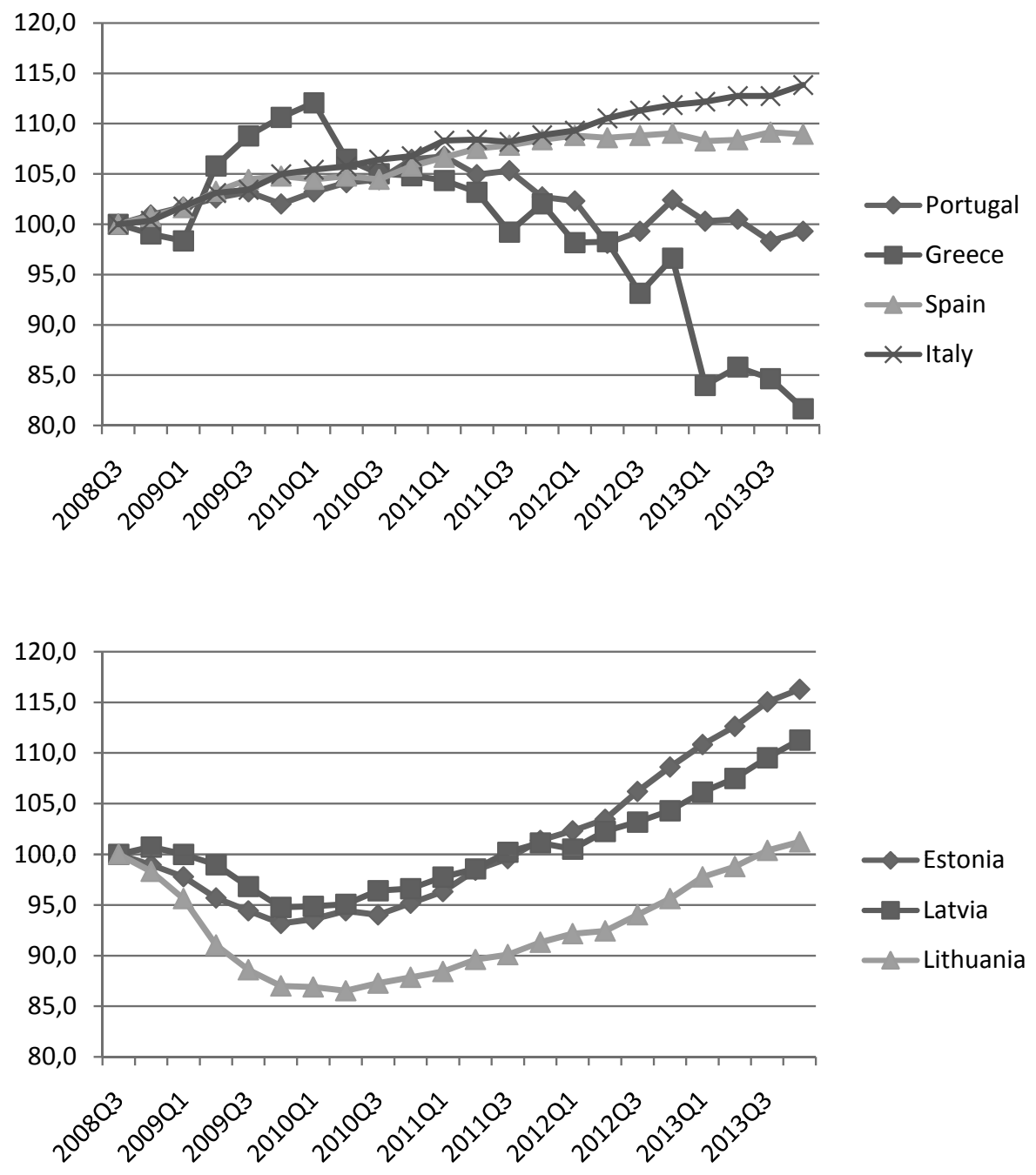

Wages and salaries in the business sector of the Baltics and the GIPS, seasonally adjusted and adjusted data by working days, third quarter of $2008=100$.

Source: Eurostat, author's calculations. 